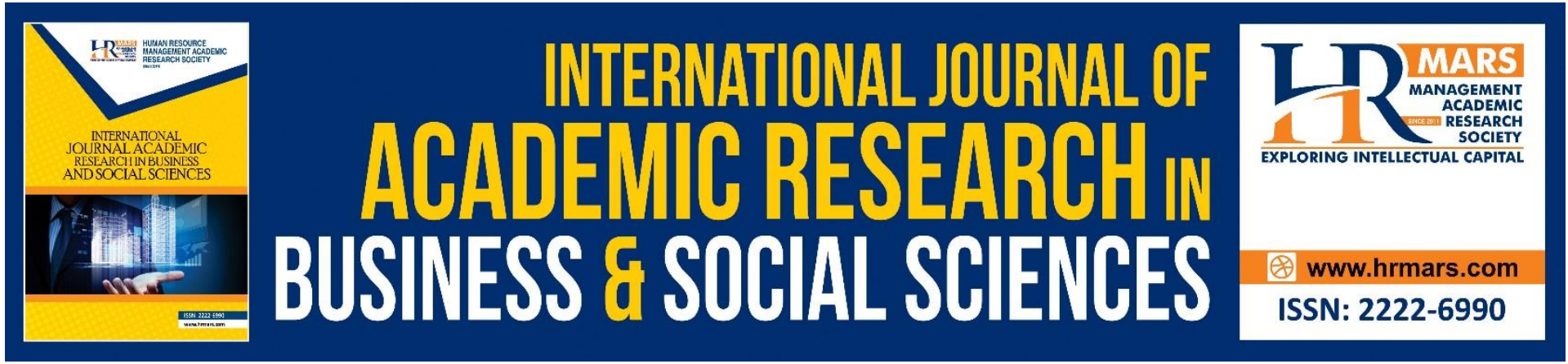

\title{
Effect of Direct Marketing on Consumer Product Uptake in Commercial Banks in Thika Town
}

Lucy Carolyne Wairimu Gitau, Doris Mbugua

To Link this Article: http://dx.doi.org/10.6007/IJARBSS/v11-i9/10577

DOI:10.6007/IJARBSS/v11-i9/10577

Received: 04 July 2021, Revised: 25 July 2021, Accepted: 18 August 2021

Published Online: 12 September 2021

In-Text Citation: (Gitau \& Mbugua, 2021)

To Cite this Article: Gitau, L. C. W., \& Mbugua, D. (2021). Effect of Direct Marketing on Consumer Product Uptake in Commercial Banks in Thika Town. International Journal of Academic Research in Business and Social Sciences, 11(9), 659-681.

Copyright: (c) 2021 The Author(s)

Published by Human Resource Management Academic Research Society (www.hrmars.com)

This article is published under the Creative Commons Attribution (CC BY 4.0) license. Anyone may reproduce, distribute, translate and create derivative works of this article (for both commercial and non-commercial purposes), subject to full attribution to the original publication and authors. The full terms of this license may be seen at: http://creativecommons.org/licences/by/4.0/legalcode

Vol. 11, No. 9, 2021, Pg. 659 - 681

http://hrmars.com/index.php/pages/detail/IJARBSS

JOURNAL HOMEPAGE

Full Terms \& Conditions of access and use can be found at http://hrmars.com/index.php/pages/detail/publication-ethics 


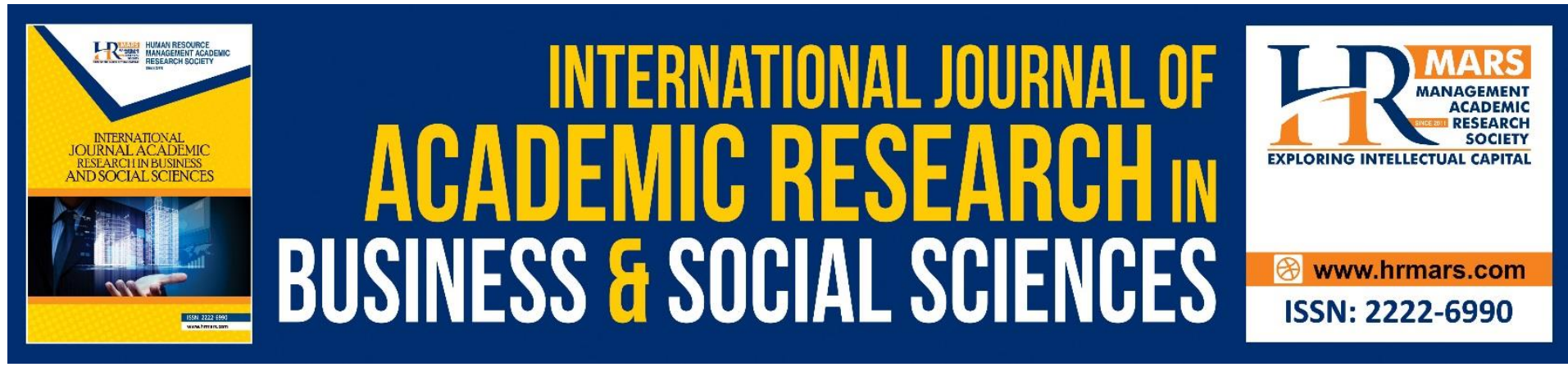

\title{
Effect of Direct Marketing on Consumer Product Uptake in Commercial Banks in Thika Town
}

\author{
Lucy Carolyne Wairimu Gitau
}

College of Human Resource and Development, Jomo Kenyatta University of Agriculture and

Technology, P. O. Box 62000, 00200 Nairobi, Kenya

Email: lucygitau001@gmail.com

Dr. Doris Mbugua, PhD

College of Human Resource and Development, Jomo Kenyatta University of Agriculture and Technology P. O. Box 62000, 00200 Nairobi, Kenya

\begin{abstract}
Abstact
The purpose of the study was to determine the effect of direct marketing on consumer product uptake in commercial banks in Thika town. The study sought to establish the effect of social media marketing, face to face selling, email marketing and telemarketing on consumer product uptake. The study adopted a descriptive cross sectional survey design and targeted 18 commercial banks operating in Thika Town. Only 16 commercial banks were involved in the study. Two commercial banks were used for piloting. The unit of observation comprised of 10 customers operating with the each of the commercial banks involved in the study making a total of 160 respondents. Structured questionnaires were employed in data collection. Both inferential and descriptive statistics were employed in analyzing the collected data. MS Excel and SPSS software were used in generating the statistics. The results of the study were presented in form of tables and figures. The findings of the study established that directing marketing practices such as social media marketing, face to face selling and telemarketing positively and significantly affect the levels of consumer product uptakes amongst commercial banks operating in Thika Town. The study however established that email market positively but insignificantly affects consumer product uptakes among the commercial banks. The study also recommends that the commercial banks operating in Thika Town should focus on enhancing their face to face selling practices since the practice positively and significantly affects the levels of consumer product uptakes. The study recommends that the commercial banks operating in Thika Town should focus on enhancing their telemarketing practices since the practice positively and significantly affects the levels of consumer product uptakes.
\end{abstract}

Keywords: Social Media Marketing, Face to Face Selling, Email Marketing, Telemarketing and Consumer Product Uptake 


\section{Introduction}

According to Kaser (2012) promotion is publicizing of products and services through a creative communication process which aims at attracting attention through a paid announcement. McDaniel, Hair and Lamb (2011) state that promotion is considered as one of the principal components of creation of brand image and maintenance of the same. Moreover, Baker (2014) stated that promotion is an informative, persuasive and complementary form of delivering information regarding an organization's products and services and is beneficial on the basis of all the information which has been provided. Rudani (2010) mentioned that attracting attention is one of factors which affects promotion, on the other hand detail information, brand awareness, characteristics and services are the factor that affect promotion (McDaniel, Hair \& Lamb, 2011).

Promotion is the way in which organizations directly try to reach, create relationships and build brand loyalty in their customers. Promotional strategies can be carried out through the five components of the promotion mix; advertising, sales promotion, personal selling, public relations, and direct marketing (Turnbull \& Fill, 2019). With the heightened importance of the financial sector, pressures are surging for more successful marketing management of the financial services. In spite of the contemporary recessions, the financial services sector is continuing to grow in terms of income and profits and consequently, has a supreme consequence on the other spheres of the economy. Thus, the growth in interest in applying promotion techniques and strategies in financial services. (Watkins \& Wright, 2010).

Rivlin and Litan (2010) explain that development of the internet has influenced the behavior of consumers and sellers since it provides new trade platforms and communication channels. Mobile, Internet, e-mail, and video are a few channels that are increasingly trending and there is need to have knowledge about these channels since consumers use the Internet as a source to find suppliers on a global level (Hennig, Malthouse \& Skiera, 2010). Companies have explored digital marketing techniques in essence video ads, sponsored content and social media promotions. Websites have been revamped, and microsites for specific products or promotions have grown. Since digital products and services, such as graphics and on-line banking, can be delivered via social media platforms, they are naturally termed as information-oriented products or services. Porter and Millar (2005) state that the digital marketing technology is an opportunity to gain competitive edge. Social media platforms have created a great opportunity to share and communicate data through electronic exchange of information. Organizations use internally to facilitate business purposes (Bandyo-padhyay, 2009). Marketers that use social media platforms in essence email marketing, social media marketing, telemarketing in their marketing strategy to affect the efficiency and effectiveness in the organizations processes also gain an edge compared to organizations which use traditional marketing in essence direct mail and print advertising approaches. Buyers on the Internet follow a buying process just as like buyers who use offline strategies when making purchases (Mishra, 2008). They search for information after a need arises, they evaluate the options which are available and then go on to make purchasing decision (Lodhi \& Shoaib, 2017).

Due to this current trends, commercial banks in Kenya have made an effort to come up with marketing strategies which are market segmented so as to boost their performances. The Kenya Banking sector has exhibited a solid growth over the past few years. The industry continues to offer notable profit opportunities for the major players(Kaser 2012). Kenya has attracted universal acclaim by expanding financial services to millions of poor households mainly via mobile phones. 
According to Baker (2012) this has impelled banks to embrace new marketing strategies so as to variegate the bank products and services. As a way of increasing the market share and demand to reach the unbanked in the local set up, banks in Kenya have embraced agency banking as one of the variegation strategies.

\section{Statement of the Problem}

Commercial banks are currently experiencing unpredictable operational environment characterized with changes in regulations, high competition, globalization, changes in consumer demands, banking license liberalization and changes in technology (Mirzaei et al., 2014). This has prompted the commercial banks to formulate different strategies for attracting customers as well as retaining the current ones. Direct marketing has been one of the major approach been implemented by the banks aiming at widening their market shares through reaching diversified customers thus increasing their performance levels. The approach further aims at convincing potential customers on availability of quality services and products been offered by the bank. However, the approach has not been resourceful in ensuring that the commercial banks attracts and retains customer and this has exposed the institutions to poor performance. According to the CBK Report(2015), several commercial banks such as Chase bank, Dubai bank and Imperial banks have collapsed in the last five years. Additionally, CBK Banks' Stability Report (2018) revealed a rise in the levels of loan defaults (non-performing loans) of $47.5 \%$ in 2017 , asset quality and decreased profit levels. Its due to this that the current study was conducted to establish how direct marketing affects customer purchase decision focusing on commercial banks operating in Thika Town.

The study is further prompted by existence of research gaps from past studies on the theme of the current study. Amrani and Correard (2011) carried out a study on the Influence of marketing on consumer buying decisions in multiple cases and the studies revealed that marketing has a positive influence on the buying decisions of consumers. However, this research differs from the one this research paper aims at conducting in that, the researchers used a multiple case study design as they believed that using more than one case would make the results more reliable and good as they believed that if a study can have similar conclusions regarding the cases, the external universalization of the findings would be extent. Ramsunder (2011) carried out a study on the impact of social media marketing on purchase decisions in the tyre industry and the study revealed that social media is a useful tool for marketers to engage with consumers during the consumer's purchase decision journey. Rawung, Mekel and Worang (2015) carried out a study on the influence of direct marketing and advertising toward customer purchase intention in applying consumer loan for government employees at Pt.bank Sulut Amurang branch and the research revealed that direct marketing and advertising has a positive effect on customer buying intention. The characteristic of each variable has positive influence to the customer purchase intention in applying consumer loan for government employees at PT.Bank Sulut Amurang Branch. Similar studies have been conducted on the effect of marketing communication in the Kenyan banking industry however, none has looked at the effect of these four direct marketing methods; social media marketing, face to face selling, email marketing on consumer purchasing decisions in commercial Banks with the population being a survey and the scope being Thika Town. Weng (2013) also states that studies have shown that consumer buyer behavior is influenced by a number of promotional activities but these studies have failed to identify which promotional methods are preferred. It was therefore recommended that due to increased use on internet, more research should be done to differentiate the influence which various methods of 
marketing has on consumer buying behavior. Hence, this creates a research gap which this study aims at filling by determining the effect of social media marketing, face to face selling, email marketing and telemarketing on consumer product uptake in commercial banks in Thika Town.

\section{Research Objectives}

i. To evaluate the effect of social media marketing on consumer product uptake in commercial banks in Thika Town.

ii. To evaluate the effect of face to face selling on consumer product uptake in commercial banks in Thika Town.

iii. To evaluate the effect of email marketing on consumer product uptake in commercial banks in Thika Town.

iv. To evaluate the effect of telemarketing on consumer product uptake in commercial banks in Thika Town.

\section{Literature Review \\ Theoretical Review \\ Expectation Confirmation Theory}

The theory was proposed by Bhattacherjee (2001) as a means of anticipating and understanding persistence objective towards the directions of new technology users. According to the theory, the intention of consumers on frequent usage of a service is greatly influenced by the individuals level of satisfaction which is swayed by first anticipations of the consumer and the consequent feeling resulting from consuming the service. The difference between perceived performance of a service or a product and first anticipation influences the decisions of customers on whether to repurchase the product or service. In the advancement of the theory, Cicic and Halilovic (2013) argue that the existing similarity between actual performance and first anticipation affects the users contentment and apparent benefit. This implies that the benefit a product or a service has on the user affects his/her satisfaction which consequently defines the intention to consume more.

According to Hsieh and Lin (2007), the theory opines that the decision of a customer to continue purchasing a product or a service a follows a number of processes that aim at attaining the intention to repurchase. The course begins before purchasing where purchasers develop anticipation of a service or a product. After the consumption, consumers develop perception in respect to the performance of the service or a product which they relate with anticipation which initially existed. According to Coursaris et al.,(2012), the extent to which anticipation of customers meets their expected performance influences levels of satisfaction. Additionally, satisfied consumers develops intention to repurchase a product while dissatisfied ones ends their repurchase intention in successive periods. In the context of the quality of the service, Klein et al., (2009) asserts that the constructs that defines the expectation of consumers includes responsiveness, assurance, empathy and assurance. In the context of the current study, commercial banks adopting digital direct marketing need to apply online platforms that encourage consumers' retention while at the same time attracting more. The online platform need to be secured, reliable, affordable, convenience and ease in the usage on the side of consumer. Additionally, when using the online platforms, firms need to include contents that will make the user to come back again for repurchases. This theory applies to the variable of social media marketing. 


\section{Theory of Reasoned Action}

Theory of reasoned action was developed by Fishbein and Ajzen in 1975 to determine how attitude predict behavior (Alam \& Sayuti, 2011). According to Fishbein and Ajzen (1975), the behavior of a person is depend on the intention, while the intention for a behavior is depend on the attitude and subjective norm. The confidence on a behavior and assessment of consequence determines the behavior of a person. Normative confidence and motivation that follows the opinion of the other people will determine the subjective norm. The interest for a behavior is influenced by interior and outside variables whereas, internal variables are influenced by attitude and outside variables are influenced by other people. Behavioral intention is important because is determined by attitudes to behaviors and subjective norms. Stronger intentions lead to increased effort to perform the behavior and also increase the possibility for the behavior to be performed. Pookulangara et al., (2011a) states that attitude toward the conduct is a component of beliefs and the evaluation of those convictions. Subjective norm is a function of a person's beliefs that helps them decided whether or not to perform the behavior; normative beliefs and the individual's motivation.

Many researchers agree that, people are more likely to perform a specific behavior if they are sure that the behavior will lead to a positive outcome, if they rationally believe that their referents will value the particular behavior and have resources, capabilities and opportunities to conduct the specific behavior (Kim \& Han, 2010).In contrast with the Theories of Reasoned Action, Kim and Han (2010) have proposed that peoples attitude guide behavior through an automatic and impulsive process instead of an intentional one as emphasized earlier by the theory. According to Cohen and Reed (2011), some researchers argue that the theory of reasoned action has failed to support the correlation between the intention of behavior and planned behavior and this was due to lack of consistency and the minimum control over a person's action. However, according to a study done by Godn and Kok (1996), it was revealed that theory of responded action is good at explaining intentions. Sigit (2008)in his study it was revealed that subjective attitudes and norms together influences consumers purchase intention, consumer attitudes moderately affect purchase intentions, and subjective norms moderately influential of purchase intentions. The theory informs on the importance of faceto-face selling to customers since the seller is in a position to judge the behaviours of the buyer ones presented with a service or a product and pre-determine the possibilities of buying.

\section{Customer Relationship Management Theory}

Customer relationship theory was developed by Westch (2005). As per the theory, management of client relationship is a mix of relationship promotion and client driven where equity theory had applied in customer relationship theory. Mylonakis (2009) defines customer relationship management as process used by associations to make a long haul relationship with its clients thus, gain their trust and increase their purchase decision. "Customer relationship management is a process used by organizations to satisfy customer needs and wants. During any interaction. More specifically CRM involves acquisition analysis and use of knowledge about customers in order to sell more goods and services" (Bose, 2002. Pg 1). Kale (2004) stated that a lot of CRM systems are usually not successful this is because organizations lack management support, lack customer life time value, have undervalued data analysis, let IT department decide what to develop and have inflexible business process. Achuama and Usoro (2008) also adds that a number of organizations have witnessed a high failure rate in CRM implementation. This is due to inaccurate customer data, organizational 
changes and fluctuations, insufficient skills, inadequate change management process and knowledge transfer gaps. Corner and Hinton (2002) argued that there is lack of performance measuring technique that can be applied to CRM the technique for measuring ROI for capital investment do not work well when applied to IT technology. In with this view, Zara and Kimilogu also state that it is difficult to measure the success of CRM.

\section{Resource Based View Theory}

The theory was proposed by Barney (1991). The theory suggests that the internal resources held by organization influences sustenance of competitive advantage and growth of the firm. According to the theory, ownership of non-imitable, rare, non-substitutable and valuable resources contributes to firms' optimal productivity that contributes to competitive advantage. The value characteristic of a resource means that a resource should have the ability of creating a valued strategy that lessens a firm weakness or surpasses that of the competitor (Barney, 1991). Similarly, the returns acquired from the adopted value strategy must be significantly higher than the investment costs associated with the resource (Mahoney \& Prahalad, 1992). The rare characteristic of a resource means that its defined price has the ability of reaching the targeted future returns. Similarly, the inimitability of a resource enables a firm to have control over the resource which serves as source of competitive advantage or sustainability. The author stipulates that when a resource highly unknown, it becomes more inimitable.

According to Cooner (1992) who supported Barney's theory, there exist different types of resources that a firm can possess and includes tangible, intangible and organizational capabilities. Tangible resources comprise of technological, financial, organizational and physical assets which are easy to identify in a firm. Intangible resources comprise of practices developed by organizations over time and contribute to results improvement. They are difficult to identify and cannot be easily copied by competitors. Organizational capabilities comprise of skills and competencies used to acquire outputs as a result of combining tangible and intangible resources.

Availability of resources either knowledge based, potentially value-creating, nonsubstitutable or imitate ensures sustainability of firms that enhances productivity. Additionally, being in possession of advanced online technology for reaching customers further contributes significantly to enhanced competitive advantage and growth. The theory contributes to the study as it informs on the need of technological advancement superior to that of competitors which enhances the growth of firms. When the commercial banks have advanced technologies that provide platforms for digital marketing such as email marketing, their chances of growth through reaching diverse customers increases. This theory informs of the need of investing in technological resources that supports direct interactions with customers through avenue such as telemarketing. 


\section{Conceptual Framework}

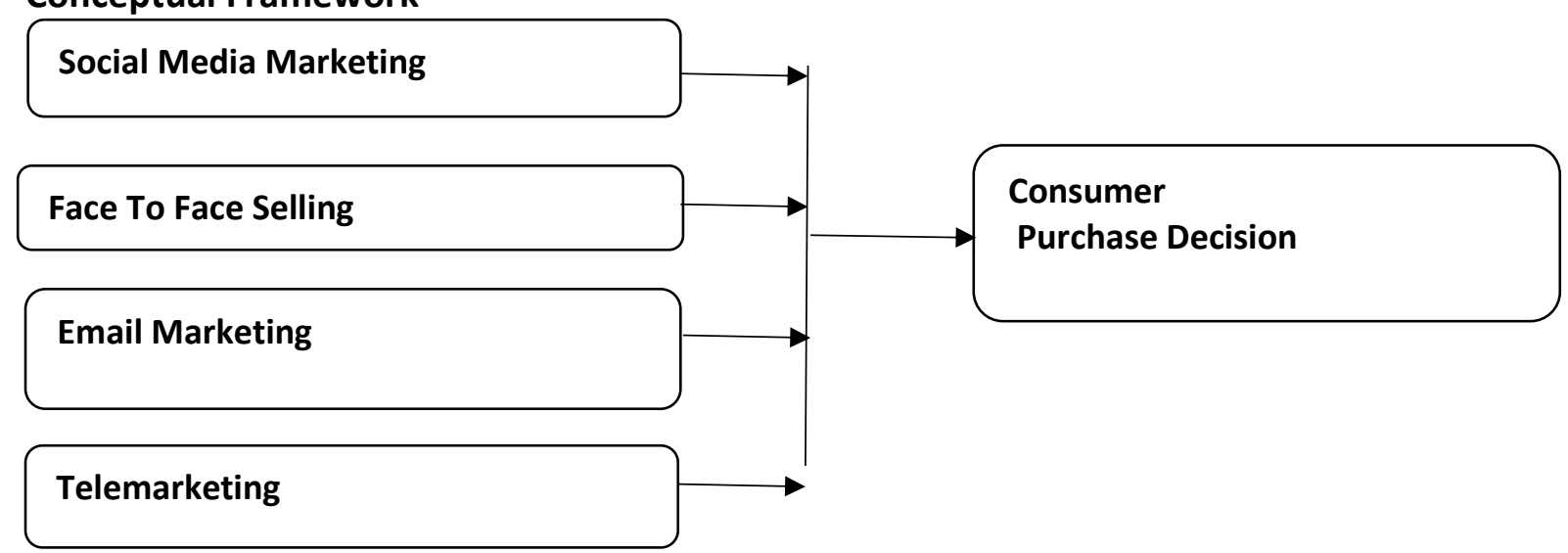

Independent Variables

Dependent Variable

Figure 1 Conceptual Framework

\section{Social Media Marketing}

According to Neilson (2009) social media marketing is the process of gaining website traffic or attention through social mediasites.Oketch(2014) defined social media marketing as the use of social networks to promote brand and services. Companies use COBRAs and eWOM to promote their brand. Munting, Moorman andSmit (2011) postulated that consumer's online brand related activities COBRAs is used when an organization upload a picture of their brand online whereas, eWOM is the use of electronic word of mouth.E-marketing is the purchasing, selling, promotion and advertisement of merchandise and services thus to influence consumer purchase intention (Vinerean, Cetina, Dumitrescu, \&Tichindelean, 2013).Social media marketing gives companies an opportunity to reach a wider market. It also helps companies increase exposure, sales and reduce marketing costs (Sumitha \& Beegam, 2014). According to Lodhiand Shoaib(2017) organizations these days use site pages to advertise their products and services. This is because it helps them reach a wider market, it is quick, less costly and they are also able to give timely and accurate information. In their concentrate on the effect of e-marketing on client purchasing behavior: A case of Karachi, Pakistan".

It was established that $80-90 \%$ of customers are attracted to online advertising therefore, it was recommended that organization should develop the use of e-marketing, e-buying and esellingto enable customer buy their goods and services on-line. Reddy(2017) examined digital promotion effect on the buyer dynamic in Nike's customer retail operations in South Africa. It was revealed that digital marketing has a positive effect on consumer decision making process. Fauser, Weidenhofer and Lorenz (2011) stated that social media marketing is an important tool that organizations can use to market their brand. In their study on touchpoint social web": An explorative study about using the social web for influencing high involvement purchase decisions it was revealed that during the early stage of consumer product uptake process organizations should use digital platforms to promote their products and during the last stage social sharing and social networks influences consumer buying behavior. Similar to this study, a study done by Charles-Henri Gros (2012) on the effect of digital media on buyers during their buy dynamic decision making cycle and the suggestions for advertisers likewise uncovered that the more expend moves through the stages the more the impact of online media diminishes. 


\section{Face-to-Face Selling}

Face-to-face selling also referred to as personal selling is one of the main marketing strategies applied by businesses. According to Yousif (2016), individual selling significantly affects the purchasing behavior of people. According to a study done by Yousif (2016) on how the youth purchase behavior for clothes was affected by the personal selling skills of the marketers. Using a questionnaire design, the study examined the individual attributes of salespersons, marketing done by different sales staff, merchandise display, and qualities of clothing stores studied the purchase behavior of their customers elicited. Salesperson are identified as a reliable customer relation management technique, however, the salespeople are unable to haggle with the clients (Yousif, 2016). Likewise, a larger part of the buyers don't have the important sales aptitudes or assume a major job stimulating the company's sales. As a result, Yousif (2016) recommended training salesperson to handle customers, and devise good negotiation skills. Erasmus and Gothan (2004) argued that a salesperson plays a complex role within a company they encourage people to make the actual purchases. In other words, the sales people had a positive effect on the purchase decision of a consumer. In fact, Erasmus and Gothan (2004) argued that companies gain a competitive edge. Compared to competitors when they utilize sales personnel more effectively. Though the study is outdated, it produces a valid argument in support of the need to market products on a face-to-face basis rather than utilizing other market promotion strategies.

\section{Email Marketing}

Email marketing is online marketing that conveys messages to an audience through electronic mail (Stokes, 2011). Drell (2011) noted that e-mail marketing is a type of outbound marketing that has one way message sent to customers informing them about company's products and services. Simpson and Mortimore (2015) investigated how direct mail marketing affected the purchase decisions of customers. The study takes the form of a systematic review identifying key texts that try to connect between the two factors. As a result, most of the information used in the process is qualitative as opposed to quantitative. Simpson noted that one of the main benefits of email marketing is in the fact that it is also personal and can rally responses from recipients effectively (Simpson \& Mortimore, 2015). Moreover, consumers feel privileged to receive customized emails about the top products offered by the company at any one time. Numerous resources collected and used in the study confirmed the view as well by agreeing that companies need to utilize strategies like direct marketing to improve the sales of a company (Simpson \& Mortimore, 2015). However, direct marketing is affected by age. Successful use of direct mail must be able to offer benefits for the company and the consumer. FahimandImran(2017) in their study on the impact of email marketing, mobile marketing and retargeting on online consumer buying behavior. It was revealed that there was email marketing does not have a positive impact on consumer buying behavior.Lodhiand Shoaib (2017) in his study on impact of e-marketing on consumer behavior: A Case of Karachi, Pakistan". It was revealed that organization should use E-mail, E-webs, YouTube and Facebook to market their products and services. Hsin \& Amin (2013). In their study on determinants of consumer behavior towards email advertisement. Findings revealed that email advertising significantly affect consumers' behavioral.

\section{Telemarketing}

In an exploratory study conducted by Verma (2009), it is clear that direct marketing has a significant impact on the extent to which people make purchases from a company. Verma 
understands that initiating a conversation is meant to elicit some reactions. As a result direct marketing communication is also directed at eliciting a positive reaction from the consumer by inducing them into making a purchase. However, Verma (2009) is skeptical of the fact that some of the consumers may fail to respond to such communications. Human beings can only process information that they feel is meaningful immediately and ignore or fail to observe other information communication in a similar manner. Therefore, Verma tries to understand what the company can do avoid such a case and elicit positive reactions from the consumers. This involves making marketing messages more appealing by incorporating any tactic at their dispersal. This may elicit varied behaviors from the consumers, for example, it may make them desire the product, whereas, in other cases, it may make them to elicit positive consumer purchase behaviors. Kumar and Raju (2013) agree point out to the same result findings. They confirm that such communications are bound to increase the sales of a company. This research also tries to link emotional response with the attitudinal and behavioral aspect of consumer buying behavior (Kumar and Raju, 2013). The study involved a large number of respondents to produce comprehensive results that could be used in the decision making process. Therefore, it tries to determine whether telemarketing elicits positive attitudes that encourage them to make purchase decisions. In conclusion, telemarketing is required for a company to make high returns from its sales.

\section{Research Methodology}

The research design of the study is descriptive cross-sectional research design. The target population comprised of eighteen commercial banks operating in Thika Town. Only 16 commercial banks were used in the study. The unit of observation will comprise of customers from the selected commercial banks. A pilot study of 10\% (20 questionnaires) of the target population was used for pre-testing as advocated by Cooper and Schindler (2008) who argue that a sample of $5-10 \%$ of target population is relevant for pilot study. The study adopted a random sampling method where 10 customers were randomly selected and involved in the study making a total of 160 respondents. Five point likerts scale questionnaires were used to collect primary data. Both descriptive and inferential statistics were employed in analysing the collected data. The analyzed data was presented in form of tables, graphs and charts to enhance easier interpretation and understanding of the research findings. The study used the following regression model:

$Y=\beta_{0}+\beta_{1} X_{1}+\beta_{2} X_{2}+\beta_{3} X_{3}+\beta_{4} X_{4}+\varepsilon$.

Where $Y=$ Consumer product uptake, $X_{1}=$ Social Media Marketing, $X_{2}=$ Face to Face Selling, $X_{3}=$ Email Marketing, $X_{4}=$ Telemarketing, $\beta_{0}=$ Regression Constant or Intercept, $\beta_{1}, \beta_{2}, \beta_{3}$ and $\beta_{4}=$ coefficients of various independent variables and $\varepsilon=$ =rror term assumed to be normally distributed with a zero variance.

\section{Results}

The study administered 160 questionnaires where 129 questionnaires were fully filled and returned. This represented a response rate of $80.6 \%$. this rate of response was considered appropriate, adequate and sufficient for the study. This is according to arguments by Mugenda and Mugenda (2013) who established that a response rate of $70 \%$ and above is very good for analysis. Ample time was given to the respondents to respond to the questionnaires greatly contributed to the high response 


\section{Descriptive Statistics and Analysis}

According to Nachmias and Nachmias(2008) descriptive statistics in research are adopted to enable the researcher describe the distributions of measures or scores. In the current study, the researcher employed both means and standard deviations in outlining the descriptive of the study's findings. The criteria followed in adopting the means and standard deviations was first rating the responses using a scale of 1-5 and then presenting the average means and standard deviation. Respondents were presented with statements pertaining to each of the variables in the questionnaires and were supposed to provide their ratings of the statements using a scale of 1-5 where $1=$ Strongly Disagree, $2=$ Disagree, $3=$ Neutral, $4=$ Agree and $5=$ Strongly Agree. The results are presented in the following subsection:

\section{Social Media Marketing}

The first objective of the study sought to assess the effects of social media marketing on customer purchase decision. Respondents were presented with statements on social media marketing and were supposed to indicate their agreement levels. The results provided in table 4.2 shows that respondents were in agreement with the statements that they find their banks' social media marketing information useful in informing them of existing products and services(mean=3.98, std.dev=1.009), that they have become aware of new products and services through the bank's social media content(mean=3.78, std.dev=0.994), that they use social media to find out how people have rated services offered by their bank (mean=3.99, std.dev=1.021) and that they have searched, bought and inquired regarding my bank's products or services from social media posts(mean=3.76, std.dev=0.345). Additionally, the respondents agreed with the statements that they have shared their knowledge about services/products offered by their bank with other people in their social network (mean=3.65, std. dev $=0.876$ ), that they frequently visit their bank's social media platforms because it offers discounts on their products to their online visitors (mean=3.61, Std.dev $=0.562$ ) and that they usually visit their bank's social media platforms because they usually put up information on new products and services(mean $=3.55$, std.dev $=0.653$ ). On average, all respondents agreed with statements on social media marketing as shown by average response mean of 3.76 and average std.dev of 0.78 . The results are consistent with Kumar et al., (2016) who noted that organizations ought to create systems that will assist them with utilizing web-based media marketing as their communication tool for better performance. 
Table 1: Descriptive Statistics on Social Media Marketing

\begin{tabular}{lcc}
\hline Social media marketing & Mean & Std.Dev \\
\hline $\begin{array}{l}\text { I find my bank's social media marketing information useful in informing } \\
\text { me of existing products and services }\end{array}$ & 3.98 & 1.009 \\
$\begin{array}{l}\text { I have become aware of new products and services through the bank's } \\
\text { social media content }\end{array}$ & 3.78 & 0.994 \\
$\begin{array}{l}\text { I use social media to find out how people have rated services offered } \\
\text { by my bank }\end{array}$ & 3.99 & 1.021 \\
$\begin{array}{l}\text { I have searched, bought and inquired regarding my bank's products or } \\
\text { services from social media posts }\end{array}$ & 3.76 & 0.345 \\
$\begin{array}{l}\text { I have shared my knowledge about services/products offered by my } \\
\text { bank with other people in my social network }\end{array}$ & 3.65 & 0.876 \\
$\begin{array}{l}\text { I frequently visit my bank's social media platforms because it offers } \\
\text { discounts on their products to their online visitors }\end{array}$ & 3.61 & 0.562 \\
$\begin{array}{l}\text { I usually visit my bank's social media platforms because they usually put } \\
\text { up information on new products and services }\end{array}$ & 3.55 & 0.653 \\
\begin{tabular}{l} 
Average \\
\hline
\end{tabular} & $\mathbf{3 . 7 6}$ & $\mathbf{0 . 7 8}$ \\
\hline
\end{tabular}

\section{Face to Face Selling}

The second objective of the study sought to assess the effects of face to face selling on customer purchase decision. Respondents were presented with statements on face to face selling and were supposed to indicate their agreement levels. The results provided in table 4.3 shows that respondents were in agreement with the statements that Face to face selling enables them to clearly understand their bank's products and services(mean=4.01, std.dev=

0.987), that information provided to them by bank salesperson regarding services/products offered has played a role in a buying decision they have made before(mean=4.23, std.dev=0.398), and that they have found information from bank salespersons useful when purchasing a new product or services from the bank(mean=3.97, std.dev $=$ 0.876). Respondents further agreed with the statement that their bank's salespersons help with products and services which are best suited for them(mean $=4.67$, std.dev=0.123). On average however, all respondents were in agreement with the statements of face to face selling as shown by a mean response of 3.868 and mean std.dev of 0.564 . The results are consistent with Yousif (2016)who established that individual selling significantly affects the purchasing behavior of people. 
Table 2: Descriptive Statistics on Face to Face Selling

\begin{tabular}{|c|c|c|}
\hline Face to Face Selling & Mean & Std.Dev \\
\hline $\begin{array}{l}\text { Face to face selling enables me to clearly understand my bank's products } \\
\text { and services }\end{array}$ & 4.01 & 0.987 \\
\hline $\begin{array}{l}\text { Information provided to me by bank salesperson regarding } \\
\text { services/products offered has played a role in a buying decision I have } \\
\text { made before }\end{array}$ & 4.23 & 0.398 \\
\hline $\begin{array}{l}\text { I have found information from bank salespersons useful when } \\
\text { purchasing a new product or services from the bank }\end{array}$ & 3.97 & 0.876 \\
\hline $\begin{array}{l}\text { My bank's salespersons help with products and services which are best } \\
\text { suited for me }\end{array}$ & 4.67 & 0.123 \\
\hline Average & 3.868 & 0.564 \\
\hline
\end{tabular}

\section{Email Marketing}

The third objective of the study sought to assess the effects of email marketing on customer purchase decision. Respondents were presented with statements on email marketing and were supposed to indicate their agreement levels. The results provided in table 4.4 shows that respondents were in agreement with the statements that they regulary receive emails from their bank which inform them of existing products/services(mean=4.1,std.dev=0.321), that information they have received through email from their bank has enabled them to know products and services best suited for their needs(mean=3.78, std.dev=1.002), that they have changed their attitude towards towards a product or services from bank emails they have received (mean $=3.92$,std.dev $=0.941$ ), that they trust on information which is sent to them by their bank via e-mail marketing(mean=4.32,std.dev=0.291) and that A bank's e-mail marketing plays an active role in building a relationship between the consumers and the organization(mean=3.89,std.dev=1.021). On average, all respondents were in agreement with all statements on email marketing as shown by average response mean of 4.002 and average std.dev of 0.715 . The results agrees with Merisevo and Raula (2004) findings which revealed that loyal customers appeared to appreciate and respond to regular communication efforts through channels like e-mails, which gave them an awareness of existing products and their costs/values.

Table 3: Descriptive Statistics on Email Marketing

\begin{tabular}{lcc}
\hline Email Marketing & Mean & Std.Dev \\
\hline $\begin{array}{l}\text { I regulary receive emails from my bank which inform me of existing } \\
\text { products/services. }\end{array}$ & 4.1 & 0.321 \\
$\begin{array}{l}\text { Information I have received through email from my bank has enabled me } \\
\text { to know products and services best suited for my needs }\end{array}$ & 3.78 & 1.002 \\
$\begin{array}{l}\text { I have changed my attitude towards towards a product or services from } \\
\text { bank emails I have received }\end{array}$ & 3.92 & 0.941 \\
$\begin{array}{l}\text { I trust on information which is sent to me by my bank via e-mail } \\
\text { marketing }\end{array}$ & 4.32 & 0.291 \\
$\begin{array}{l}\text { A bank's e-mail marketing plays an active role in building a relationship } \\
\text { between the consumers and the organization }\end{array}$ & 3.89 & 1.021 \\
Average & $\mathbf{4 . 0 0 2}$ & $\mathbf{0 . 7 1 5}$ \\
\hline
\end{tabular}




\section{Telemarketing}

The fourth objective of the study sought to assess the effects of telemarketing on customer purchase decision. Respondents were presented with statements on telemarketing and were supposed to indicate their agreement levels. The results provided in table 4.5 shows that respondents were in agreement with the statements that they find calls from a bank sales representative useful (mean=4.12, std.dev=0.608), that they have made a purchase(s) following their bank's telemarketing call(mean=3.87, std.dev $=0.871$ ), and that they consider banking telemarketing useful in gaining knowledge on products and services before making a buying decision (mean=3.76, std.dev=0.762). Additionally, the respondents agreed that bank telemarketing has influenced them to purchase a product or services they had no intention of purchasing before the call(mean=3.77, std.dev=1.324) and that they find bank telemarketing helpful in awareness of their bank's new products and services and ongoing promotions(mean=4.31,std.dev=0.196). On average, all respondents were in agreement with statements on telemarketing as shown by the average response mean of 3.966 and average std.dev of 0.752 . The results are in tandem with Erum (2017) who established that through email marketing, financial institutions were in a position to provide more and detailed information on products and service to prospective and existing customers which enhanced their sales.

Table 4: Descriptive Statistics on Telemarketing

\begin{tabular}{lll}
\hline Telemarketing & Mean & Std.Dev \\
\hline $\begin{array}{l}\text { I find calls from a bank sales representative useful } \\
\text { I have made a purchase(s) following my bank's telemarketing call }\end{array}$ & 4.12 & 0.608 \\
I consider banking telemarketing useful in gaining knowledge on & 3.87 & 0.871 \\
$\begin{array}{l}\text { products and services before making a buying decision } \\
\text { Bank telemarketing has influenced me to purchase a product or services }\end{array}$ & 3.76 & 0.762 \\
$\begin{array}{l}\text { I had no intention of purchasing before the call } \\
\text { I find bank telemarketing helpful in awareness of my bank's new }\end{array}$ & 4.31 & $\mathbf{0}$ \\
$\begin{array}{l}\text { products and services and ongoing promotions } \\
\text { Average }\end{array}$ & $\mathbf{3 . 9 6 6}$ & $\mathbf{0 . 7 5 2}$ \\
\hline
\end{tabular}

\section{Consumer Product Uptake}

The study sought to analyze the consumers decision to purchase products and services from the commercial banks. First, the respondents were requested to indicate the number of services/products they have purchased from their respective commercial banks. The results presented in figure 4.6 shows that $74.7 \%$ of respondents had purchased one service/product, $17.6 \%$ had purchased two products/service and only $7.7 \%$ of respondents had purchased three and above products/services. The results shows implies that majority of respondents purchased only a single product/service from their respective commercial banks. 


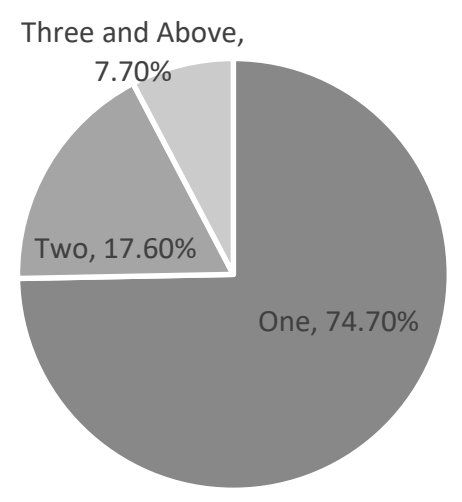

Figure 2: Product/Services Purchased

Secondly, the respondents were requested to indicate the number of accounts they hold with their respective commercial banks. The results in figure 4.7 shows that $84.3 \%$ of respondents had only one account, $10.6 \%$ had two accounts while $5.1 \%$ had three and above accounts. The results shows that majority of the commercial bank customers only operate a single account with their respective banks.

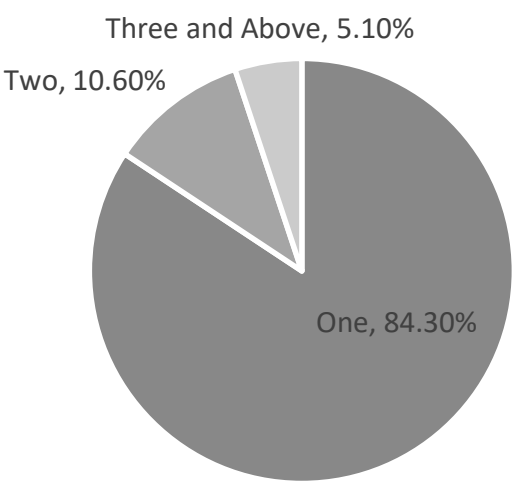

Figure 3: Number Of Accounts Held

Thirdly, respondents were presented with statements on consumer product uptake and were supposed to indicate their agreement levels. The results provided in table 4.6 shows that respondents were in agreement with the statements that they have had prejudice of a bank's product or services before consuming it due to promotional content they have encountered regarding the product/service $($ mean $=4.14$, std.dev $=0.801)$, that their awareness of their bank's products and services influences their purchase decision(mean=4.36, std.dev=0.248), that their bank's promotional content has made them aware of available alternatives when making a purchase decision on a product/service offered (mean=3.89, std.dev=0.925) and that cost of product or service influences they purchasing decision (mean=4.16, std.dev=0.217). Respondents further agreed with the statements that thei bank of choice is influenced by their needs (mean $=4.98$, std.dev $=0.093$ ) and that they have made a purchase decision of a product/service offered by their bank due to promotional content regarding the product/service $($ mean $=3.81$, std.dev $=0.825)$. On average, all respondents were in agreement with statements on consumer product uptake as shown by average response mean of 4.22 and std.dev of 0.518. The results concurs with Guinn and Semenik (2008) who posits that the 
rise of the Internet has had a positive effect on direct marketing as a promotional tool, as it has allowed companies to be targeted as it enables direct advertising activities towards a particular group of individuals with a limited loss of time

Table 5: Descriptive Statistics on Consumer product uptake

\begin{tabular}{|c|c|c|}
\hline Customer Purchase Decision & Mean & Std.Dev \\
\hline $\begin{array}{l}\text { I have had prejudice of a bank's product or services before consuming it } \\
\text { due to promotional content I have encountered regarding the } \\
\text { product/service }\end{array}$ & 4.14 & 0.801 \\
\hline $\begin{array}{l}\text { My awareness of my bank's products and services influences my } \\
\text { purchase decision }\end{array}$ & 4.36 & 0.248 \\
\hline $\begin{array}{l}\text { My bank's promotional content has made me aware of available } \\
\text { alternatives when making a purchase decision on a product/service } \\
\text { offered }\end{array}$ & 3.89 & 0.925 \\
\hline Cost of product or service influences my purchasing decision & 4.16 & 0.217 \\
\hline My bank of choice is influenced by my needs & 4.98 & 0.093 \\
\hline $\begin{array}{l}\text { I have made a purchase decision of a product/service offered by my bank } \\
\text { due to promotional content regarding the product/service }\end{array}$ & 3.81 & 0.825 \\
\hline Average & 4.22 & 0.518 \\
\hline
\end{tabular}

\section{Inferential Statistics \\ Correlation Results}

The correlation results show that social media marketing positively and significantly affects consumer product uptake amongst the commercial banks. This is shown by correlation coefficient value of 0.205 and a $p$-value of 0.012 . This bears implication that enhancing social media marketing practices results to improved customer purchase decision. This is consistent with Adegbuyi et al (2015) who established that engagement with people in the social media enhance the visibility of the products and services to target and existing customers which enhances customer reachability thus boosting the performance of the business. The correlation results also shows that face to face selling positively and significantly affects consumer product uptake amongst the commercial banks. This is shown by correlation coefficient value of 0.363 and a $p$-value of 0.004 . This bears implication that enhancing face to face selling practices results to improved customer purchase decision. This is in tandem with Khan (2016) who established that one-on-one marketing positively impacts the customers intention of purchasing due to the fact that customers were in direct contact with the sellers and would receive direct responses on any query.

The correlation results further shows that email marketing positively and but insignificantly affects consumer product uptake amongst the commercial banks.

This is shown by correlation coefficient value of 0.104 and a $p$-value of 0.073 . This bears implication that enhancing email marketing practices results to insignificant improvements on customer purchase decision. This concurs with Shoaib and Lodhi (2014) who found that use of email marketing impacted positively customer purchase and intention to buy behaviors. According to the results, the banks that made use of email marketing had a high customer retention rates which impacted positively on the growth and performances. The correlation results finally shows that telemarketing positively and significantly affects consumer product uptake amongst the commercial banks. This is shown by correlation 
coefficient value of 0.132 and a p-value of 0.043 . This bears implication that enhancing telemarketing practices enhances consumer product uptakes. The results tallies with Wanjuki (2014) findings which revealed that digital marketing practices such as mobile marketing positively impacts the levels of customer service in the bank. Additionally, mobile marketing enhances visibility of the bank's products and increases awareness of the available products and services.

Table 6: Correlation Analysis

\begin{tabular}{|c|c|c|c|c|c|c|}
\hline & & $\begin{array}{l}\text { Social } \\
\text { Media } \\
\text { Marketin } \\
\text { g }\end{array}$ & $\begin{array}{l}\text { Face to } \\
\text { Face } \\
\text { Selling }\end{array}$ & $\begin{array}{l}\text { Email } \\
\text { Marketin } \\
\text { g }\end{array}$ & $\begin{array}{l}\text { Telemarketin } \\
\text { g }\end{array}$ & $\begin{array}{l}\text { Consume } \\
r \text { product } \\
\text { uptake }\end{array}$ \\
\hline \multirow[t]{2}{*}{$\begin{array}{l}\text { Social Media } \\
\text { Marketing }\end{array}$} & $\begin{array}{l}\text { Pearson } \\
\text { Correlatio } \\
\mathrm{n}\end{array}$ & 1 & & & & \\
\hline & Sig. (2-tailec & & & & & \\
\hline \multirow[t]{2}{*}{$\begin{array}{l}\text { Face to Face } \\
\text { Selling }\end{array}$} & $\begin{array}{l}\text { Pearson } \\
\text { Correlatio } \\
\mathrm{n}\end{array}$ & 0.152 & 1 & & & \\
\hline & $\begin{array}{l}\text { Sig. } \\
\text { tailed) }\end{array}$ & 0.482 & & & & \\
\hline \multirow[t]{2}{*}{$\begin{array}{l}\text { Email } \\
\text { Marketing }\end{array}$} & $\begin{array}{l}\text { Pearson } \\
\text { Correlatio } \\
\mathrm{n}\end{array}$ & 0.043 & 0.196 & 1 & & \\
\hline & $\begin{array}{ll}\text { Sig. } & (2- \\
\text { tailed) } & \end{array}$ & 0.342 & 0.134 & & & \\
\hline \multirow[t]{2}{*}{$\begin{array}{l}\text { Telemarketin } \\
\mathrm{g}\end{array}$} & $\begin{array}{l}\text { Pearson } \\
\text { Correlatio } \\
\mathrm{n}\end{array}$ & 0.294 & 0.099 & $.451^{*}$ & 1 & \\
\hline & $\begin{array}{l}\text { Sig. } \\
\text { tailed) }\end{array}$ & 0.094 & 0.228 & 0.011 & & \\
\hline \multirow[t]{3}{*}{$\begin{array}{l}\text { Consumer } \\
\text { product } \\
\text { uptake }\end{array}$} & $\begin{array}{l}\text { Pearson } \\
\text { Correlatio } \\
\mathrm{n}\end{array}$ & $.205^{* *}$ & $.363^{* *}$ & $.104^{* *}$ & $.132 * *$ & 1 \\
\hline & $\begin{array}{l}\text { Sig. } \\
\text { tailed) }\end{array}$ & 0.012 & 0.004 & 0.073 & 0.043 & \\
\hline & $\mathrm{N}$ & 129 & 129 & 129 & 129 & 129 \\
\hline
\end{tabular}

\section{Multiple Regression Analysis}

The study conducted a multiple regression analysis aiming at assessing the degree of association between the variables of the study. The analysis was conducted at $95 \%$ confident level. The results presented in table 4.8 shows existence of strong relationship between social media marketing, face to face selling, email marketing and telemarketing and consumer product uptake as depicted by $R=0.789$. The $R$-Squared value which represents the coefficient 
of determination was 0.623 implying that social media marketing, face to face selling, email marketing and telemarketing accounts for $62.3 \%$ of consumer product uptake.

Table 7: Model Summary

\begin{tabular}{lllll}
\hline$R$ & R Square & Adjusted R Square & $\begin{array}{l}\text { Std. Error of the } \\
\text { Estimate }\end{array}$ & \\
\hline $789^{a}$ & 0.623 & 0.443 & 2.231476 \\
\hline
\end{tabular}

The study further conducted ANOVA test to assess the statistical significance of the model of the study in testing the relationships between the study variables. The results presented in table 8 shows that the model of the study was statistically significant. This is shown by comparing the value of F-calculated with the value of F-critical. The value of F-calculated, 18.6104 exceeds that value of F-critical at $(4,124)$ which is 2.45 implying that the model is statistically significant.

Table 8: ANOVA (Model Significance)

\begin{tabular}{|c|c|c|c|c|c|c|}
\hline Mode & & $\begin{array}{l}\text { Sum } \\
\text { Squares }\end{array}$ & of & Mean Square & & Sig. \\
\hline \multirow[t]{3}{*}{1} & Regression & 52.228 & 4 & 13.057 & 18.6104 & $0.012341^{b}$ \\
\hline & Residual & 86.998 & 124 & 0.701597 & & \\
\hline & Total & 139.226 & 128 & & & \\
\hline
\end{tabular}

Table 9 presents the coefficients of the model used in the study. The results shows that social media marketing affects consumer product uptake to a positive and significant level. This is depicted by a beta value of 0.325 and Sig value of 0.009 . This bears an implication that increasing the social medial marketing practices with one unit results to a 0.325 unit increase on consumer product uptake. This is consistent with Adegbuyi et al (2015) who established that engagement with people in the social media enhance the visibility of the products and services to target and existing customers which enhances customer reachability thus boosting the performance of the business.

The coefficient results also shows that one on one selling affects consumer product uptake to a positive and significant level. This is depicted by a beta value of 0.345 and Sig value of 0.002 . This bears an implication that increasing the one on one selling practices with one unit results to a 0.345 unit increase on consumer product uptake. This is in tandem with Khan (2016) who established that one-on-one marketing positively impacts the customers intention of purchasing due to the fact that customers were in direct contact with the sellers and would receive direct responses on any query.

The coefficient results further shows that email marketing affects consumer product uptake to a positive but insignificant level. This is depicted by a beta value of 0.069 and Sig value of 0.097. This bears an implication that increasing the email marketing practices with one unit results to a 0.069 unit increase on consumer product uptake. This concurs with Shoaib and Lodhi (2014) who found that use of email marketing impacted positively customer purchase and intention to buy behaviors. According to the results, the banks that made use of email marketing had a high customer retention rates which impacted positively on the growth and performances. The coefficient results finally shows that telemarketing affects consumer product uptake to a positive and significant level. This is depicted by a beta value of 0.132 and Sig value of 0.0027 . This bears an implication that increasing the telemarketing practices with one unit results to a 0.132 unit increase on consumer product uptake. The results tallies with 
Wanjuki (2014) findings which revealed that digital marketing practices such as mobile marketing positively impacts the levels of customer service in the bank. Additionally, mobile marketing enhances visibility of the bank's products and increases awareness of the available products and services.

Table 9: Model Coefficients

\begin{tabular}{llllll}
\hline & \multicolumn{3}{l}{ Unstandardized Coefficients } & \multicolumn{3}{l}{ Standardized Coefficients } \\
\hline Predictors & B & Std. Error & Beta & T & Sig. \\
\hline (Constant) & 0.433 & 0.141 & & 3.0709 & 0 \\
Social Media Marketing & 0.325 & 0.167 & 0.301 & 1.9461 & 0.009 \\
Face to Face Selling & 0.345 & 0.132 & 0.298 & 2.6136 & 0.002 \\
Email Marketing & 0.069 & 0.322 & 0.745 & 0.2143 & 0.097 \\
Telemarketing & 0.132 & 0.101 & 0.199 & 1.3069 & 0.0027 \\
\hline
\end{tabular}

The model therefore becomes

Consumer product uptake $=\mathbf{0 . 4 3 3}+0.345$ (Face to Face Selling) +0.325 (Social Media Marketing) + 0.132 (Telemarketing) $+\mathbf{0 . 0 6 9}$ (Email Marketing)

The model results shows that face to face selling bears the most significant effect on consumer product uptake, followed by social media selling, then telemarketing and finally email marketing.

\section{Conclusion}

The findings of the study led to conclusions that social media marketing positively and significantly affects consumer product uptakes amongst commercial banks in Thika Town. The results further established that social media practices such as providing customers with useful social media marketing information on existing products and services, buying and making enquiries on the bank's products and services, and sharing knowledge on the bank's services and products significantly and positively affects consumer product uptakes amongst commercial banks in Thika Town. The findings of the study also led to conclusions that face to face selling positively and significantly affects consumer product uptakes amongst commercial banks in Thika Town. The results also established that face to face selling practices such as providing face to face selling which enables customers to clearly understand their bank's products and services, providing information provided through bank salesperson regarding services/products offered which plays a role in a buying decision, providing useful information through the bank salespersons when purchasing a new product or services from the bank and having salespersons who help customers with products and services which are best suited for them significantly and positively affects consumer product uptakes amongst commercial banks in Thika Town.

The findings of the study further led to conclusions that email marketing positively but insignificantly affects consumer product uptakes amongst commercial banks in Thika Town. The results also established that email marketing practices such as regularly sending emails to customers on the existing products/services, sending informative emails that changes the consumer's attitudes on prevailing products/service, sending trust worth information through emails and having an e-mail marketing that plays an active role in building a relationship between the consumers and the organization significantly and positively affects consumer product uptakes amongst commercial banks in Thika Town. The findings of the study finally led to conclusions that telemarketing positively and significantly affects consumer product 
uptakes amongst commercial banks in Thika Town. The results also established that telemarketing practices such as making useful calls to the customers, making calls that convince customers to purchase available products/services, having telemarketing practices useful in gaining knowledge on products and services before making a buying decision, having a telemarketing approach that influences customers to purchase a product or services they had no intention of purchasing and having telemarketing practices that re helpful in making the customers aware of their bank's new products and services and ongoing promotions significantly and positively affects consumer product uptakes amongst commercial banks in Thika Town.

The study contributes to the existing knowledge on the effects of direct marketing on consumer product uptake amongst commercial banks and can acts a reference to future studies in the same area. The study specifically adds knowledge on how aspects of directing marketing i.e Social Media Marketing, Face To Face Selling, Email Marketing and Telemarketing impacts consumer purchase decisions which can be applied in other sectors apart from commercial banks. The findings of the study advances and confirms the propositions of the theories adopted in the study and interlinks the theories with the findings of the study.

\section{Recommendations for the Study}

The study recommends that the commercial banks operating in Thika Town should focus on enhancing their social media marketing practices since the practice positively and significantly affects the levels of consumer product uptakes. This can be achieved through practices such as providing customers with useful social media marketing information on existing products and services, buying and making enquiries on the bank's products and services, and sharing knowledge on the bank's services. The study also recommends that the commercial banks operating in Thika Town should focus on enhancing their face to face selling practices since the practice positively and significantly affects the levels of consumer product uptakes. This can be achieved through practices such as providing face to face selling which enables customers to clearly understand their bank's products and services, providing information provided through bank salesperson regarding services/products offered which plays a role in a buying decision, providing useful information through the bank salespersons when purchasing a new product or services from the bank and having salespersons who help customers with products and services which are best suited for them.

The study further recommends that the commercial banks operating in Thika Town should focus on improving their email marketing practices since the practice positively but insignificantly affects the levels of consumer product uptakes. This can be achieved through practices such as regularly sending emails to customers on the existing products/services, sending informative emails that changes the consumer's attitudes on prevailing products/service, sending trust worth information through emails and having an e-mail marketing that plays an active role in building a relationship between the consumers and the organization. The study finally recommends that the commercial banks operating in Thika Town should focus on enhancing their telemarketing practices since the practice positively and significantly affects the levels of consumer product uptakes. This can be achieved through practices such as making useful calls to the customers, making calls that convince customers to purchase available products/services, having telemarketing practices useful in gaining knowledge on products and services before making a buying decision, having a telemarketing approach that influences customers to purchase a product or services they had no intention 
of purchasing and having telemarketing practices that re helpful in making the customers aware of their bank's new products and services and ongoing promotions.

\section{Acknowledgement}

Thanks to the almighty God without whose blessing this study would not have been possible. I would also like to express my sincere gratitude and thanks to my supervisor Dr. Doris Mbugua for guidance during my master's program, for the time devoted to guide me throughout the project development. I also extend my gratitude to my parents and my spouse Michael Mwenda who have devoted their time to guiding me throughout and have been patient with me during my absence while doing course work. Thanks to my colleagues for sharing knowledge and valuable assistance during my study.

\section{References}

Achuama, P., \& Usoro, A. (2008). Dancing with Stars: CRM and SMEs in Developing Countries, Proceedings of First International Business Conference, Dearborn MI, USA.

American Marketing Association. (2015). Marketing dictionary: "Brand". Retrieved from http://www.marketing-dictionary.org/ama.

Correard, S., \& Amrani, H. E. (2011). The impact of marketing on customer's behaviour. Dissertation in Marketing, 15 higher education credits (ECTS).

Baker, M. (2014). Marketing Strategy and Management. USA. Macmillan International Higher Education.

Bandyo-padhyay, N. (2002). E-commerce: Context, Concepts and Consequences', UK,Berkshire: McGraw-Hill International, London

Central Bank of Kenya. (2009). Bank Supervision Annual Report.

Central Bank of Kenya. (2011). Kenya's Financial Sector Stability Report.

Charles-Henri, G. (2012). The influence of Social Media on consumers during their purchase decision-making process and the implications for marketers(Masters). Dublin University.

Cooper, D. R., \& Schindler, P. S. (2014). Business research methods $\left(12^{\text {th }}\right.$ ed). New York, NY: McGraw-Hill education.

Erasmus, A. C., \& Gothan, A. J. (2004). The complex role of a salesperson in an appliance sales context. Journal of Consumer Sciences, 32(1), 1-10.

Fahim, I.,\& Imran, K. (2017). The impact of email marketing, mobile marketing and retargeting on online consumer buying behavior(Masters). Haaga-Helia University.

Fauser, S.G. Wiedenhofer, J. \& Lorenz, M., (2011). "Touchpoint social web": an explorative study about using the social web for influencing high involvement purchase decisions. Problems and Perspectives in Management, 9(1), 39-45.

Guinn, T., Allen, C., \& Semenik, R. (2008). Advertising and Brand Promotion. Wyoming. Cengage Learning.

Kale, S. H. (2004). CRM failure and the seven deadly sins. Marketing management, 13(5), 4246.

Kaser, K. (2012). Advertising and Sales Promotion. USA, Cengage Learning.

Khan, S. (2016). Impact Of One To One Marketing On The Customer Equity And Customer Purchase Intention Of Luxury Brands (Masters). Effat University.

Kumar, A., Bezawada, R., Rishika, R., Janakiraman, R., \&Kannan, P. K. (2016). From social to sale: Theeffects of firm-generated content in social media on customer behavior. Journal of Marketing, 80(1), 7-25. 
Kumar, D. P., \& Raju, K. V. (2013). The role of advertising in consumer decision making. IOSR Journal of Business and Management, 14(4), 37-45.

Lodhi, S., \& Shoaib, M. (2017). Impact of E-Marketing on Consumer Behaviour: A Case of Karachi, Pakistan". Journal of Business and Management. 19(1), 90-101.

Marshall, C., \& Rossman, G. B. (2010). Designing Qualitative Research(illustrated). New York, NY: Sage

McDaniel, C., Hair, J., \& Lamb, C. (2013). Essentials of Marketing . USA. Cengage Learning.

Mishra, A. K. (2008). Marketing to and serving customers through the internet: an overview and research agenda. Journal of the Academy of Marketing Science 30, 286- 295.

Mugenda, A., \&Mugenda, O. (2013). Research methods: Quantitative and qualitative approaches. Nairobi: ACTS Press.

Mugenda, O. M., \& Mugenda, A. G. (2015). Research Methods - Qualitative and Quantitative Approaches. Nairobi: African Center for Technology Studies.

Nachmias, C. F., \& Nachmias, D. (2008). Research Methods in the Social Sciences,(5 ${ }^{\text {th }}$ ed.). London, UK: Sr. Martin Press Inc.

Oketch, C. E. (2014). Social media marketing and consumer behavior of thefirms in the media industry in Kenya(Masters). University of Nairobi.

Porter, M. E. (2005). Competitive advantage. New York: Free Press.

Ramsunder. (2011). Impact of social media marketing on purchase decisions in the tyre industry. Nelson Mandela Metropolitan University Business School

Rani, P. (2014). Factors influencing consumer behavior. International journal of current research and academic review, 2(9), 52-61.

Rawung, M., \& Worang, P. (2015). Influence of direct marketing and advertising toward customer purchase intention in applying consumer loan for government employees at Pt.bank Sulut Amurang branch.

Reddy, G. (2017). Digital marketing impact on the consumer decision making process in Nike's customer retail operations in South Africa(Doctorate).University of Pretoria.

Rivlin, A., \& Litan, R. (2010). The Economic Payoff from the Internet Revolution: Brookings Task Force on the Internet. USA. Brookings Institution Press.

Rudani, R. B. (2010). Basics of Marketing Management (Theory and Practice). USA. S Chand Publishing.

Simpson, J., \& Mortimore, H. (2015). The influence of direct mail marketing on buyer purchasing decisions: a qualitative analysis of perceptions by age group. Journal of Research Studies in Business and Management, 1(1), 119-142.

Stokes, R. (2011). eMarketing: The essential guide to digital marketing (4th ed). Quirk Pty Ltd

Sumitha, R., \& Beegam, S. R. (2014). Building Brand Loyalty through Social Media Marketing. Indian Journal of Research, 3(7), 2.

Turnbull, S., \& Fill, C. (2019). Marketing Communications. United Kingdom. Pearson UK.

Verma, S. (2009). Do all advertising appeals influence consumer product uptake: An exploratory study. Global Business Review, 10(1), 33-43.

Vinerean, S., Cetina, I., Dumitrescu, L., \& Tichindelean, M. (2013). The Effects of Social Media Marketing on Online Consumer Behavior. International Journal of Business and Management, 66-79.

Weng, J. (2013). "Consumers' personal values and sales promotion preferences effect on behavioral intention and purchase satisfaction for consumer product". Asia Pacific Journal of Marketing and Logistics, 25(1), 70 -101. 
INTERNATIONAL JOURNAL OF ACADEMIC RESEARCH IN BUSINESS AND SOCIAL SCIENCES

Vol. 11, No. 9, 2021, E-ISSN: 2222-6990 @ 2021 HRMARS

Yousif, R. O. (2016). The impact of personal selling on the purchasing behavior towards clothes: A case study on the youth category. International Journal of Marketing Studies, 8(5), 128-135. 